\title{
ANALISIS KONDISI ATMOSFER SAAT KEJADIAN HUJAN LEBAT DAN ANGIN KENCANG DI PROBOLINGGO BERDASARKAN CITRA SATELIT DAN CITRA RADAR
}

\author{
NUR HABIB MUZAKI *, ESTRI DINIYATI, RIZALDO RADITYA PRATAMA, \\ ADITYA MULYA
}

Program Studi Meteorologi, Sekolah Tinggi Meteorologi Klimatologi dan Geofisika (STMKG) Jl. Perhubungan I No. 5 Komplek BMKG Pondok Betung Bintaro, Pondok Aren, Tangerang Selatan, Banten Kode Pos 15221, Telp.(021) 73691621

*email : nur.habib.muzaki@stmkg.ac.id

\begin{abstract}
Abstrak. Fenomena cuaca ekstrem hujan lebat dan angin kencang melanda empat kecamatan di Kabupaten Probolinggo, Jawa Timur pada tanggal 3 Januari 2020 pukul 17.00 WIB. Berdasarkan data dari Badan Penanggulangan Bencana Daerah (BPBD) Jawa Timur, kejadian hujan lebat disertai angin kencang ini mengakibatkan sebanyak 204 rumah warga mengalami kerusakan. Penelitian ini menggunakan data pengindraan jauh berupa Radar C-Band dan Satelit Himawari-8 serta data renalisis Copernicus ECMWF. Data diolah menjadi peta spasial dan grafik yang kemudian di analisis secara deskriptif. Hasil analisis data radar menunjukan bahwa nilai reflektivitas maksimum mencapai 43 $\mathrm{dBZ}$ serta kecepatan angin yang mencapai $13.57 \mathrm{~m} / \mathrm{s}$ dengan curah hujan sebesar 15.83 $\mathrm{mm} / \mathrm{jam}$ pada pukul 10.00 WIB. Berdasarkan analisis Satelite Himawari-8 suhu puncak awan mencapai -73.1 oC serta data labilitas atmosfer yang menunjukan bahwa kondisi atmosfer labil dimana hal ini dapat mengindikasikan peluang terjadinya hujan lebat disertai angin kencang. Nilai vortisitas pada lapisan $1000 \mathrm{mb}-500 \mathrm{mb}$ bernilai negatif dan nilai kelembapan berkisar antara $85 \%$ - 90\% serta nilai anomali suhu permukaan laut yang positif dan adanya windshear mengakibatkan konvergensi massa udara yang dapat memicu adanya pertumbuhan awan konvektif sebagai penyebab kejadian hujan lebat serta angin kencang di Kabupaten Probolinggo, Jawa Timur.
\end{abstract}

Kata kunci: Hujan Lebat, Angin Kencang, Himawari-8, Radar C-Band

\begin{abstract}
The phenomenon of extreme weather, heavy rain and strong winds hit four sub-districts in Probolinggo Regency, East Java on January 3, 2020 at 17.00 WIB. Based on data from the East Java Regional Disaster Management Agency (BPBD), the incidence of heavy rain and strong winds resulted in damage to as many as 204 houses. This study uses remote sensing data in the form of C-Band Radar and Himawari-8 Satellite and Copernicus ECMWF renalysis data. The data is processed into spatial maps and graphs which are then analyzed descriptively. The results of data analysis show that the reflectivity value reaches $43 \mathrm{dBZ}$ and the wind speed reaches $13.57 \mathrm{~m} / \mathrm{s}$ with a rainfall of $15.83 \mathrm{~mm} /$ hour at $10.00 \mathrm{WIB}$. Based on the analysis of the Himawari-8 Satellite, the peak temperature of the clouds reached $-73.1 \mathrm{oC}$ and the atmospheric lability data showed that the atmosphere was unstable, which could indicate the possibility of heavy rain and strong winds. The value of vortices in the $1000 \mathrm{mb}-500 \mathrm{mb}$ layer is negative and the humidity value ranges from $85 \%-90 \%$ and a positive sea surface temperature anomaly value and the presence of windshields result in convergence of air masses which can support convective cloud growth as the cause of heavy rain events and strong winds in Probolinggo Regency, East Java.
\end{abstract}

Keywords: Heavy Rain, Strong Wind, Himawari-8, C-Band Radar 


\section{Pendahuluan}

Negara Indonesia dilalui oleh garis ekuator sehingga merupakan negara yang memiliki surplus energi karena mendapat pancaran sinar matahari yang lebih banyak. Hal ini menjadikan Indonesia sebagai wilayah pembentukkan awan konvektif yang intensif dengan curah hujan yang cukup tinggi (Endarwin, 2012). Awan-awan konvektif yang terbentuk di wilayah Indonesia membawa hujan lebat, kilat dan guntur (Tjayono, 2008). Hal ini mengakibatkan wilayah Indonesia memiliki suatu pola cuaca yang dinamis serta dipengaruhi oleh skala meteorologi baik skala gobal, regional maupun lokal (Zakir dkk., 2010). Kejadian cuaca ekstrem terjadi ketika kondisi atmosfer pada suatu wilayah berada dalam kondisi yang labil yang dapat memicu pertumbuhan awan-awan konvektif seperti awan cumulonimbus. Salah satu kejadian cuaca ekstrem ini yaitu hujan lebat dan angin kencang yang memberikan dampak berupa kerusakan rumah, pohon tumbang dan banjir.

Kejadian hujan dan angin kencang telah sering melanda wilayah Indonesia dan pernah diteliti sebelumnya. Seperti penelitian analisis angin kencang di daerah Nabire yang menggunakan beberapa indikator dengan analisis cuaca secara global, regional dan lokal serta parameter cuaca lainya yang dominan (Sampe, 2017). Kemudian dalam penelitian hujan lebat di Pulau Bangka disimpulkan bahwa terdapat gangguan cuaca berupa windshear serta relative humidity yang cukup tinggi diatas Pulau Bangka yang berpotensi besar untuk pembentukan awan yang besar dan luas. Intensitas curah hujan di suatu wilayah dapat di kategorikan hujan lebat jika intensitas yang terjadi sebesar $100 \mathrm{~mm} / \mathrm{hari}$ atau $10 \mathrm{~mm} / \mathrm{jam}$ hingga 20 $\mathrm{mm} / \mathrm{jam}$ (Fadholi, 2015). Kecepatan angin dapat dikategorikan angin kencang jika memiliki kecepatan diatas $12.5 \mathrm{~m} / \mathrm{s}$ atau 25 knot.

Semakin banyak dan berkembangnya alat pengindraan jauh, kejadian hujan lebat dan angin kencang dapat dianalisis dan dikaji menggunakan bantuan citra satelit dan citra radar. Hal ini disebabkan karena citra satelit dan citra radar sangat efektif dalam mengidentifikasi fenomena hujan lebat dan angin kencang. Citra satelit yang umumnya digunakan adalah citra satelit kanal Infrared (IR). Akan tetapi citra satelit dianggap belum cukup dalam mengalaisis mengenai struktur awan konvektif pada lapisan bawah, sehingga digunakan citra radar untuk mendapatkan analisis lebih detail. Dengan penggunaan dua alat pengindraan jauh ini untuk menganalisis kejadian hujan lebat dan angin kencang diharapkan dapat menganalisis dan mengkaji lebih detail terhadap kejadian cuaca ekstrem di Indonesia.

Hujan lebat dan angin kencang yang terjadi Desa Pajarakan, Probolinggo, Jawa Timur pada 3 Januari 2020 memiliki dampak yang besar yang menyebabkan kerusakan pada rumah warga. Kerusakaan yang di alami oleh warga mulai dari kerusakaan ringan, sedang dan berat. Berdasarkan data dari Badan Penanggulangan Bencana Daerah (BPBD) Jawa Timur, kejadian hujan lebat disertai angin kencang ini mengakibatkan sebanyak 204 rumah warga mengalami kerusakan. Kejadian yang terjadi pada sore hari ini tidak hanya membuat kerusakan pada rumah warga melainkan menyebabkan banyak pohon tumbang yang mengganggu jalannya transportasi akibat pohon yang tumbang menghalangi jalan di Desa Pajarakan.

Tujuan penelitian ini adalah untuk menganalisis kondisi atmosfer saat kejadian hujan lebat dan angin kencang di Desa Pajaraka, Probolinggo dengan memanfaatkan citra satelit dan citra radar $C$-Band. 


\section{Metode Penelitian}

\subsection{Lokasi Penelitian}

Penelitian dilakukan di Desa Pajarakan, Probolinggo Jawa Timur yang memiliki koordinat antara $112^{\circ} 00^{\prime}-114^{\circ} 0^{\prime}$ Bujur Timur dan 6 $6^{\circ} 50^{\prime}-8^{\circ} 50^{\prime}$ Lintang Selatan dengan luas 56,67 km² seperti peta pada Gambar 1 .

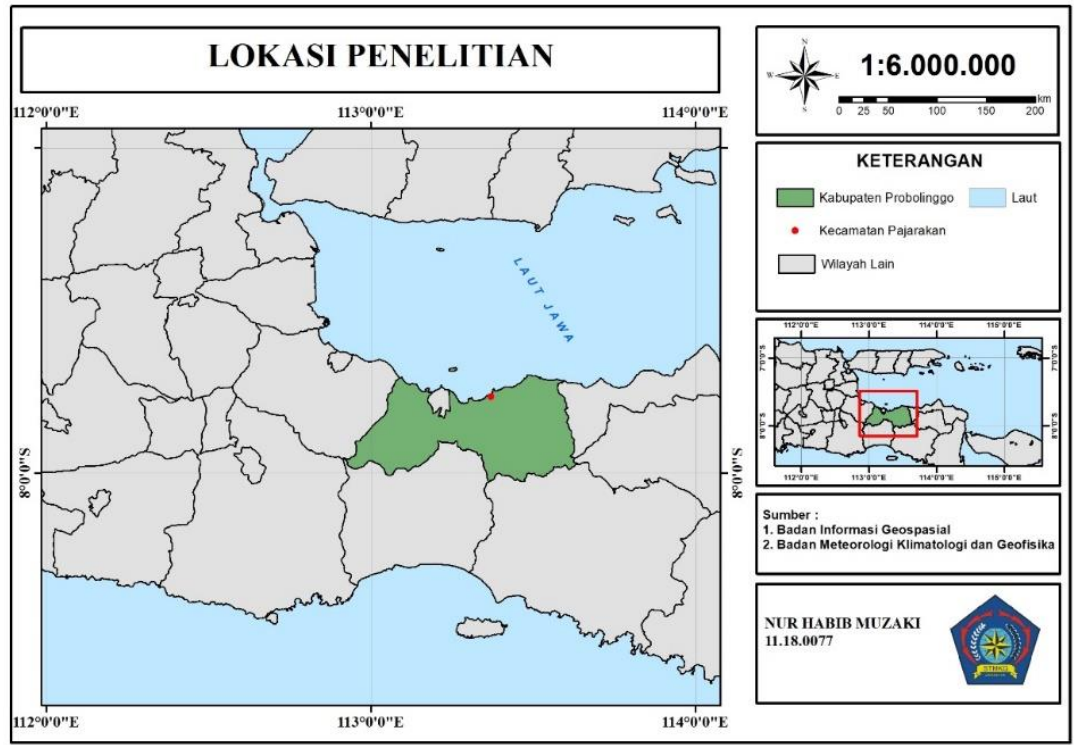

Gambar 1. Peta wilayah Penelitian

\subsection{Data dan Metode}

Data yang digunakan dalam penelitian ini adalah data pada tanggal 3 Januari 2020 dengan data peta dinamika udara skala global yang terdiri dari indeks Nino 3.4, Madden Julian Oscillation (MJO), indeks Indian Ocean Dipole (IOD) yang di unduh dari situs www.bom.gov.au/climate/mjo dan www.noaa.gov._Untuk data Sea Surface Temperature (SST), Streamline, Relative Humidity (RH) dan vortisitas berasal dari Copernicus European Centre for Medium-Range Weather Forecasts (ECMWF) yang di unduh dari https://apps.ecmwf.int/datasets/data/interim-fulldaily/levtype $=\mathrm{sfc} /$ yang kemudian diolah menggunakan aplikasi GraADS. Untuk data Showalter Stability Index (SI), Lifted Index (LI), K-Index (KI), Severe Weather Threat (SWEAT) dan Convective Avaible Potential Energy (CAPE) diambil dari satelit Himawari-8 yang diolah pada aplikasi SATAID dengan tools synop yang kemudian data diolah kembali menggunakan aplikasi Microsoft Excel menjadi grafik. Data suhu puncak awan, time series dan kontur didapatkan dari data Satelit Himawari-8 dengan kanal Infrared Enhance (IR) yang diperoleh dari ftp://satelit.bmkg.go.id yang diolah dengan aplikasi SATAID. Kemudian data suhu puncak awan kemudian diolah kembali menggunakan aplikasi GrADS. Raw data radar cuaca Jawa Timur terletak di Stasiun Meteorologi Kelas I Juanda Sidoarjo. Raw data yang digunakan berupa raw data reflektivitas (Z), Kecepatan radial (V) dan lebar spectral (W) yang kemudian diolah sehingga menghasilkan produk data CMAX dBZ yang di overlay dengan data SWI, data CAPPI Velocity dan data SRI. Metode yang digunakan adalah dengan membuat data dalam bentuk peta spasial dan grafik yang kemudina dianalisis secara deskripktif. 


\section{Hasil dan Pembahasan}

\subsection{Analisis Skala Global}

\subsubsection{Indeks Nino 3.4}

Berdasarkan Gambar 2, nilai indeks Nino 3.4 pada 3 Januari 2020 ditandai dengan lingkaran berwarna kuning yaitu sebesar 0.56 . Hal tersebut menandakan bahwa pada bulan Januari 2020 aktivitas ENSO berada pada fase El Nino namun dalam keadaan lemah. Kondisi ini cenderung tidak mendukung kejadian hujan lebat dan angin kencang di Probolinggo, Jawa Timur pada tanggal 3 Januari 2020.

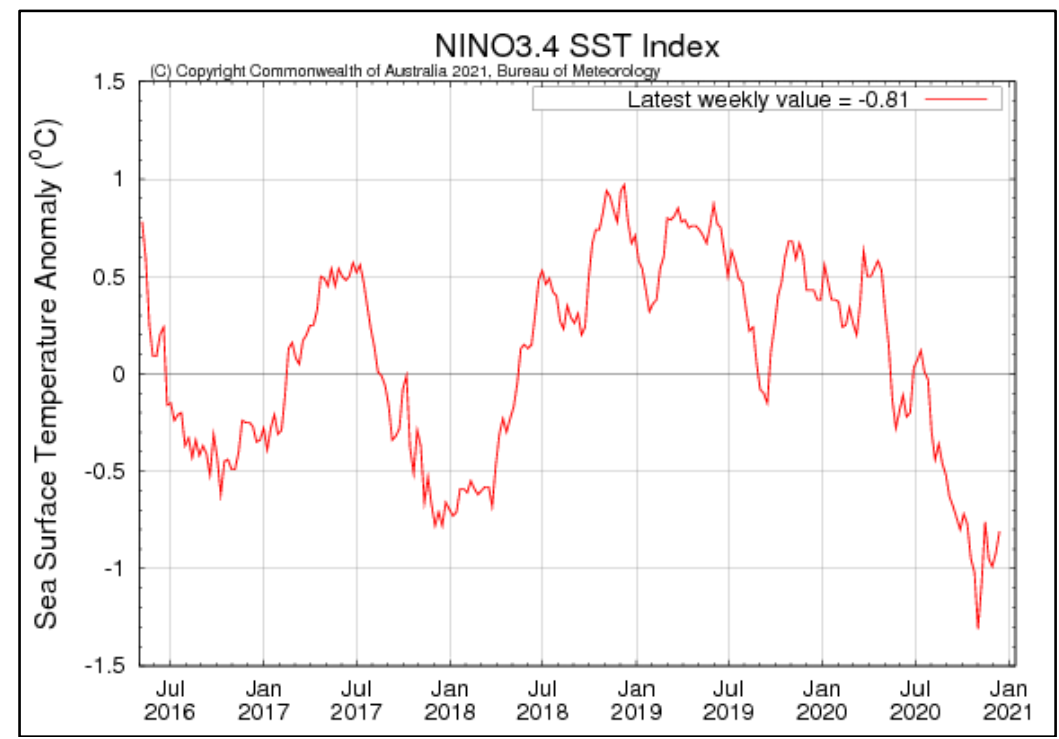

Gambar 2. Indeks Nino 3.4

\subsubsection{MJO (Madden Julian Oscillation)}

Berdasarkan Gambar 3 , menunjukkan bagaimana aktivitas pergerakan MJO 1-31 Januari 2020. Terlihat bahwa pada 3 Januari 2020 , MJO terdapat di fase 1 dan terdapat di dalam lingkaran. Hal ini menunjukan bahwa MJO tidak berpengaruh terhadap kejadian hujan lebat dan angin kencang di Probolinggo.

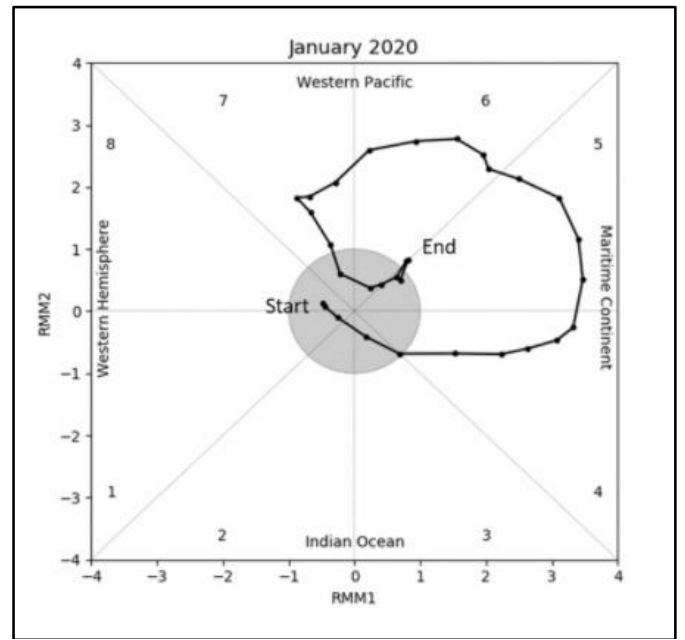

Gambar 3. Diagram Fase MJO 1 Januari - 31 Maret 2019 


\subsubsection{IOD (Indian Ocean Dipole)}

Berdasarkan Gambar 4, nilai indeks IOD pada 3 Januari 2020 ditandai dengan lingkaran berwarna biru yaitu sebesar 0.17 . Hal ini menunjukan bahwa aktivitas IOD sedang dalam fase positif sehingga tidak mendukung terjadinya kejadian hujan lebat dan angin kencang di Probolinggo.

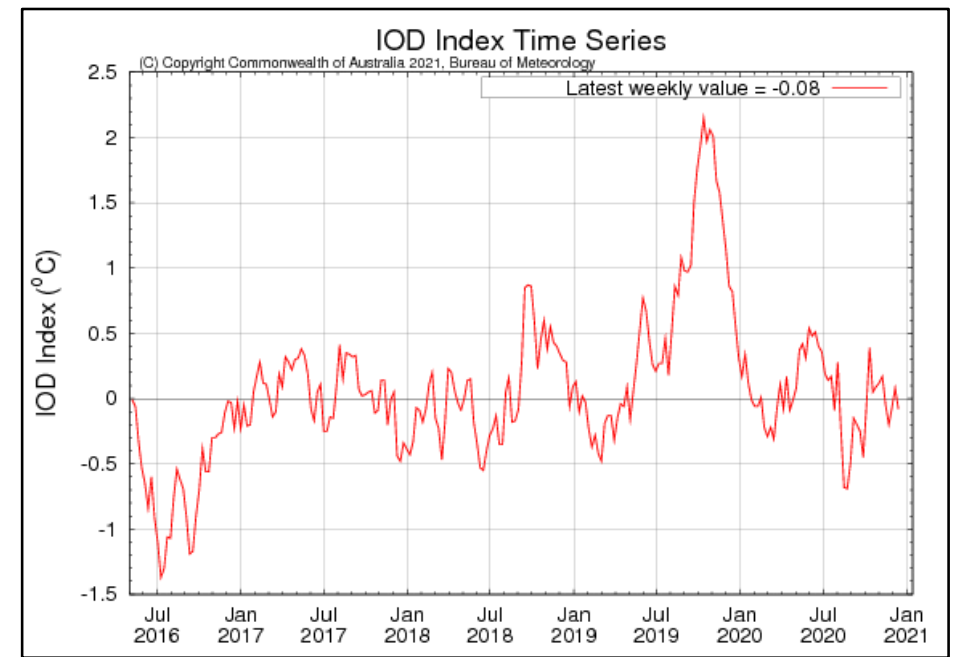

Gambar 4. Indeks IOD (India Ocean Dipole)

\subsubsection{Analisis Sea Surface Temperature (SST)}

Berdasarkan Gambar 5, nilai anomali SST di Indonesia sebesar $0^{\circ} \mathrm{C}$ hingga $2{ }^{\circ} \mathrm{C}$. Untuk lingkaran berwarna merah menunjukan nilai anomali SST di pesisir wilayah Probolinggo sebesar $1.6{ }^{\circ} \mathrm{C}$ hingga $1.8{ }^{\circ} \mathrm{C}$. Berdasarkan Gambar 6, nilai SST di Indonesia secara umum sebesar $26.5^{\circ} \mathrm{C}$ hingga $31{ }^{\circ} \mathrm{C}$. Untuk lingkaran berwarna merah menunjukan nilai SST di pesisir wilayah Probolinggo sebesar $29{ }^{\circ} \mathrm{C}$ hingga $30{ }^{\circ} \mathrm{C}$. Nilai anomali SST yang positif dan SST yang tinggi menunjukan bahwa kondisi di perairan Indonesia memiliki suhu yang lebih hangat dari kondisi normalnya. Hal ini menyebabkan peningkatan penguapan yang akan memicu terbentuknya awan-awan konvektif di wilayah Indonesia, khususnya wilayah Probolinggo.

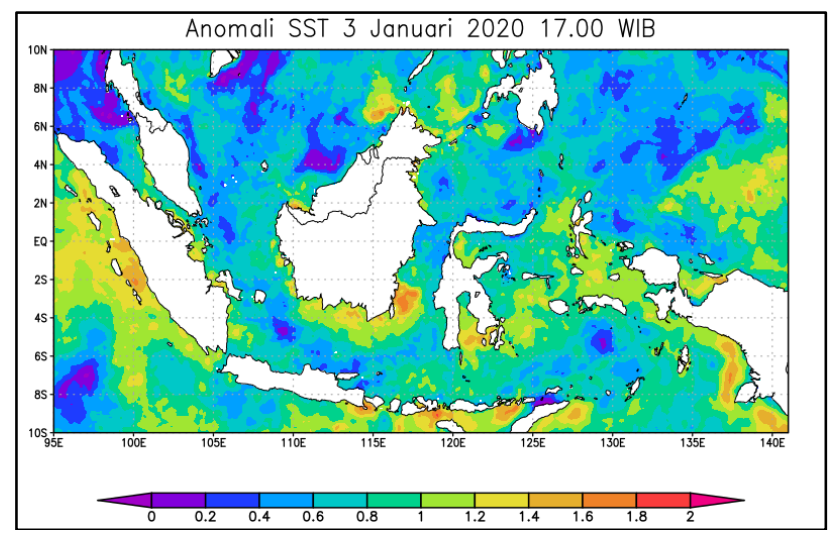

Gambar 5. Anomali Sea Surface Temperature pada 3 Januari 2020 


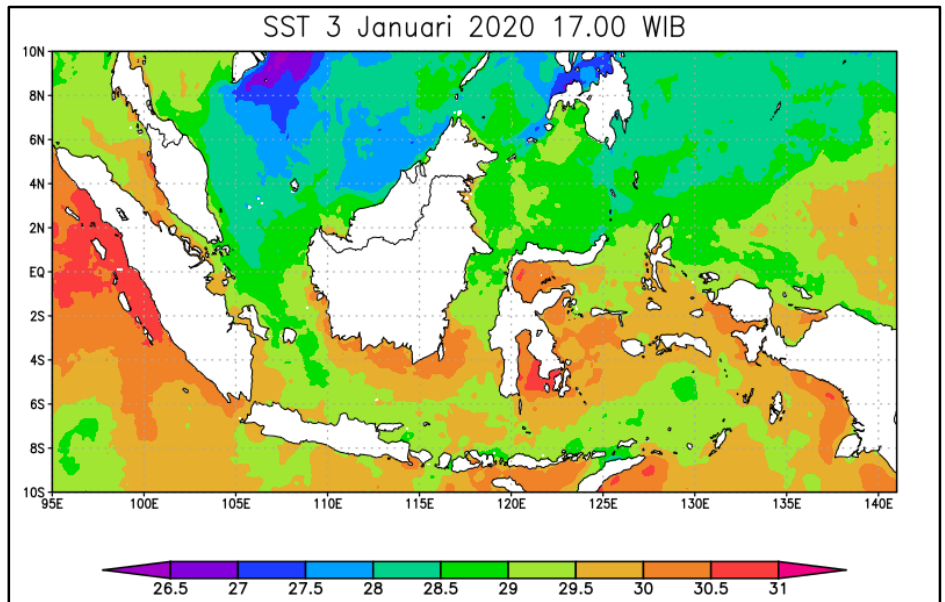

Gambar 6. Sea Surface Temperature pada 3 Januari 2020

\subsection{Analisis Skala Regional}

\section{Streamline}

Berdasarkan Gambar 7, massa udara di wilayah Indonesia dominan bergerak dari arah Barat Laut ke Timur Laut. Pada gambar (a) terlihat di wilayah Probolinggo terdapat pertemuan dua massa udara, sedangkan pada gambar (b) dan (c) terdapat shearline di wilayah Probolinggo serta pada gambar. Hal ini mengakibatkan adanya pola konvergensi di wilayah Probolinggo yang memicu terbentuknya awanawan konvektif sebelum terjadi hujan lebat dan angin kencang pada jam 17.00 WIB.

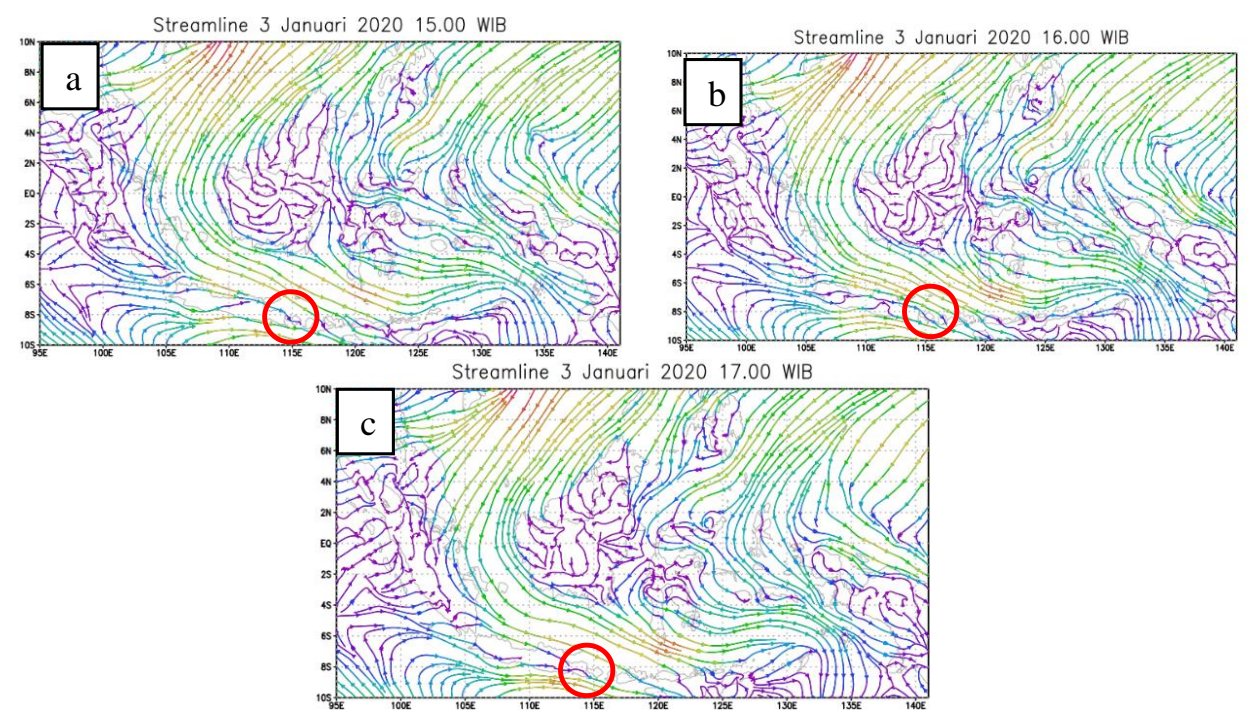

Gambar 7. Streamline Indonesia lapisan 1000 mb pada 3 Januari 2020 (a) jam 15.00 WIB (b) jam 16.00 WIB (c) jam 17.00 WIB

\subsection{Analisis Skala Lokal}

\subsubsection{Relative Humidity (RH)}

Nilai RH secara vertikal di Kecamatan Pajarakan, Probolinggo pada tanggal 3 Januari 2020 pad lapisan $1000 \mathrm{mb}$ hingga lapisan $100 \mathrm{mb}$ ditunjukkan pada Gambar 8. Pada kotak berwarna biru, nilai RH pada jam 06.00 UTC hingga 09.00 UTC 
sebesar 85\%-90\% pada lapisan $1000 \mathrm{mb}$ hingga $500 \mathrm{mb}$. Nilai RH yang tinggi pada lapisan $1000 \mathrm{mb}$ hingga $500 \mathrm{mb}$ yang tinggi ini menunjukan bahwa kondisi atmosfer sebelum terjadinya hujan lebat dan angin kencang mengandung banyak uap air yang mendukung pertumbuhan awan-awan konvektif di Kecamatan Pajarakan. Untuk jam 10.0 UTC nilai RH ditunjukkan kotak berwarna merah sebesar 80\%-85\% dari lapisan $1000 \mathrm{mb}$ hingga $800 \mathrm{mb}$. Sedangkan untuk lapisan $800 \mathrm{mb}$ hingga $300 \mathrm{mb}$ memiliki nilai Relative Humidity sebesar 75\% - 80\% serta untuk lapisan $300 \mathrm{mb}$ hingga $200 \mathrm{mb}$ memiliki nilai RH sebesar 55\%-60\% dan untuk lapisan 200 mb hingga 100 mb memiliki nilai RH sebesar 75\%-80\%.

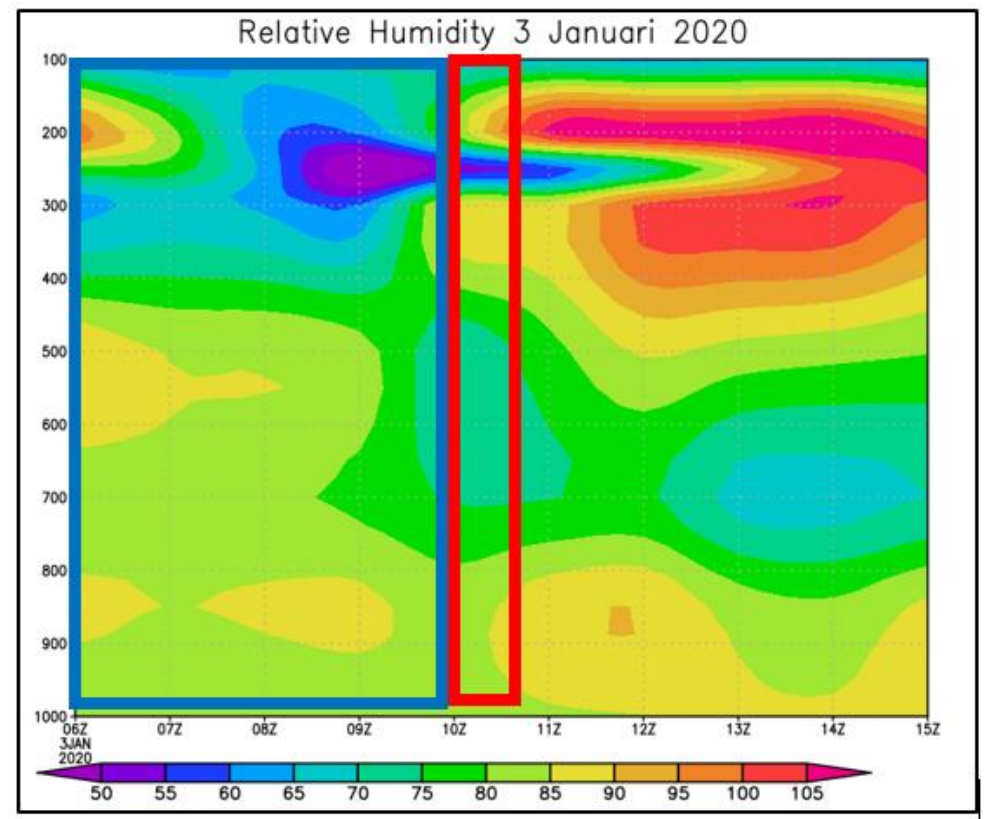

Gambar 8. Relative Humidity

\subsubsection{Vortisitas}

Berdasarkan Gambar 9, nilai vortisitas pada kotak berwarna biru menunjukan vortisitas sebelum kejadian hujan lebat dan angin kencang yaitu pada jam 06.00 UTC hingga 09.00 UTC. Terlihat pada lapisan $1000 \mathrm{mb}$ hingga $500 \mathrm{mb}$ nilai vortisitas sebesar -0.00021 sampai dengan -0.00003. Nilai yang negaitf ini menunjukan bahwa adanya kecendrungan massa udara yang membentuk sirkulasi siklonik. Akibatnya terjadi konvergensi di wilayah Pajarakan yang memicu terbentuknya awan-awan konvektif. Untuk kotak berwarna merah menunjukan nilai vortisitas saat kejadian hujan lebat dan angin kencang pada jam 10.00 UTC, dimana dari lapisan $1000 \mathrm{mb}$ hingga $700 \mathrm{mb}$ sebesar -0.00021 hingga -0.00018 sedangkan untuk lapisan $700 \mathrm{mb}$ hingga $500 \mathrm{mb}$ sebesar -0.00018 sampai dengan 0 . Hal ini menunjukan bahwa pada saat kejadian hujan lebat dan angin kencang terdapat konvergensi di wilayah Pajarakan. 


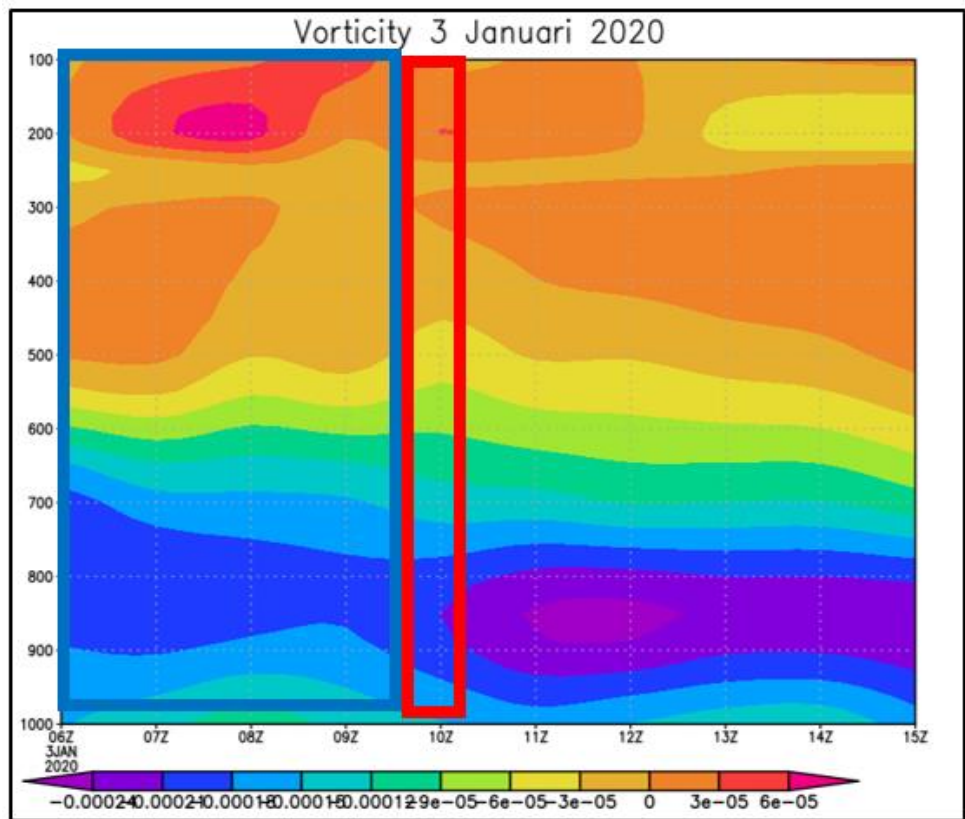

Gambar 9. Vortisitas lapisan $1000 \mathrm{mb}-100 \mathrm{mb}$

\subsection{Analisis Stabilitas Atmosfer}

\subsubsection{Nilai Showalter Stability Index (SSI)}

Berdasarkan Gambar 10, nilai Showalter Stability Index (SSI) pada jam 10.00 UTC yang ditunjukkan pada kotak berwarna merah sebesar $2.3^{\circ} \mathrm{C}$. Sedangkan nilai SSI sebelum kejadian hujan lebat dan angin kencang pada jam 06.00 UTC hingga 09.50 UTC sebesar $2.3^{\circ} \mathrm{C}$ hingga $2.5^{\circ} \mathrm{C}$. Nilai SSI yang berada pada rentang $1^{\circ} \mathrm{C}$ hingga $3{ }^{\circ} \mathrm{C}$ berpotensi untuk terjadinya hujan lebat. Sehingga dengan melihat nilai SSI pada jam 06.00 UTC hingga 10.00 UTC ini berpotensi terjadinya hujan lebat.

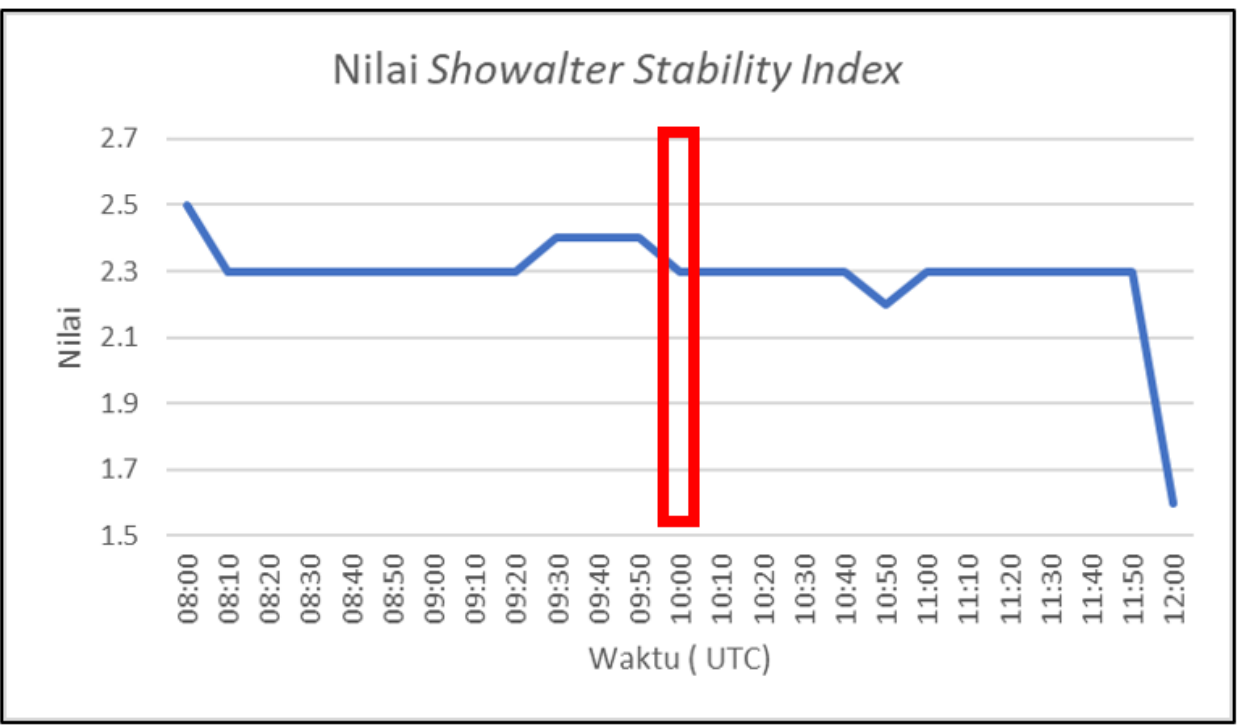

Gambar 10. Grafik nilai Showalter Stability Index (SSI) 


\subsubsection{Nilai Lifted Index (LI)}

Berdasarkan Gambar 11, nilai Lifted Index pada jam 10.00 UTC ditunjukkan pada kotak berwarna merah sebesar $-2.6{ }^{\circ} \mathrm{C}$. Untuk nilai Lifted Index sebelum kejadian hujan lebat dan angin kencang pada jam 06.00 UTC hingga 09.50 UTC sebesar $2.6^{\circ} \mathrm{C}$ hingga $-2.7^{\circ} \mathrm{C}$. Nilai Lifted Index yang negative ini menunjukan bahwa kondisi atmosfer dalam keadaan labil, sehingga mendukung proses terbentuknya awan-awan konvektif.

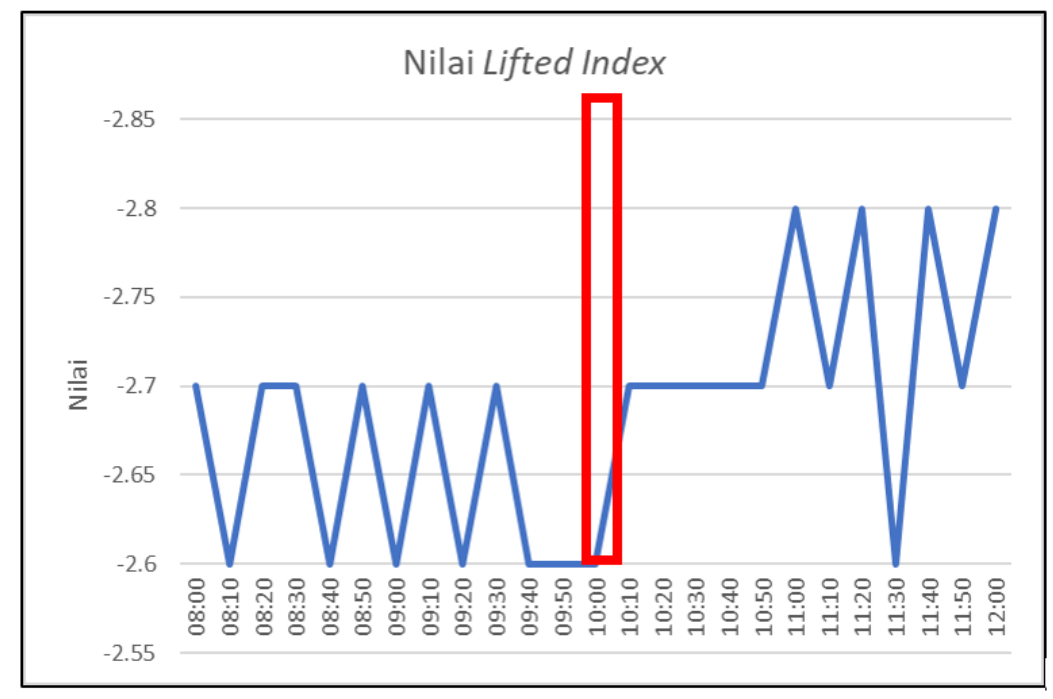

Gambar 11. Grafik nilai Lifted Index (LI)

\subsubsection{Nilai K-Index}

Berdasarkan Gambar 12, nilai K-Index (KI) pada jam 10.00 UTC ditunjukkan pada kotak berwarna merah sebesar $32.7^{\circ} \mathrm{C}$. Untuk nilai KI sebelum kejadian hujan lebat dan angin kencang yaitu pada jam 06.00 UTC hingga 09.50 UTC sebesar $32.3^{\circ} \mathrm{C}$ hingga $32.5^{\circ} \mathrm{C}$. Hal ini menunjukan bahwa adanya konveksi yang kuat dan potensi terjadinya Thunderstroms sebesar $85 \%$.

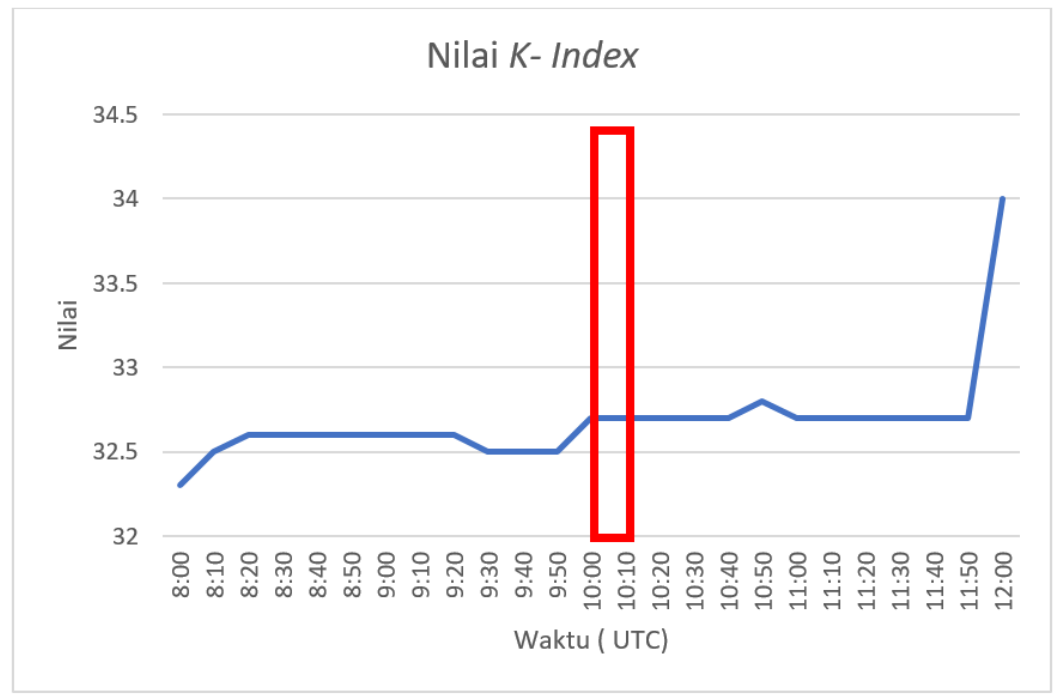

Gambar 12. Grafik nilai K-Index (KI) 


\subsubsection{Nilai Severe Weather Threat (SWEAT)}

Berdasarkan Gambar 13, nilai Severe Weather Threat (SWEAT) pada jam 10.00 UTC ditunjukkan pada kotak berwarna merah sebesar 259. Untuk nilai SWEAT sebelum kejadian hujan lebat dan angin kencang pada jam 06.00 UTC hingga 09.50 UTC sebesar 257 sampai 260. Hal ini menunjukkan bahwa adanya potensi terjadinya cuaca buruk di wilayah Pajarakan.

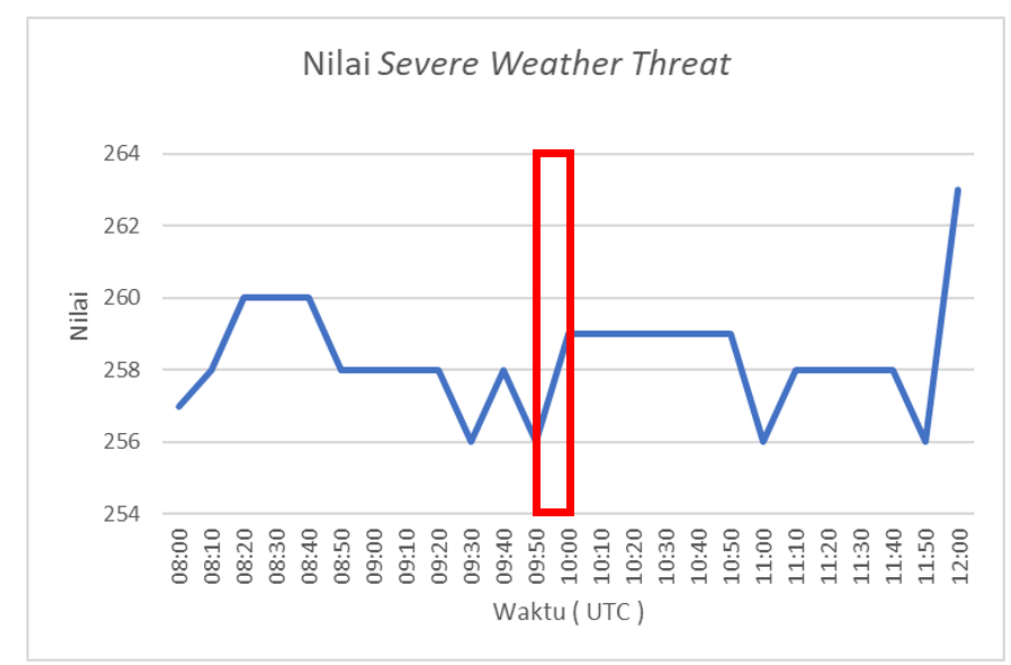

Gambar 13. Grafik nilai Severe Weather Threat (SWEAT)

\subsubsection{Nilai Convective Avaible Potential Energy (CAPE)}

Berdasarkan Gambar 14, nilai Convective Avaible Potential Energy (CAPE) pada jam 10.00 UTC ditunjukkan pada kotak berwarna merah sebesar $732 \mathrm{~J} / \mathrm{kg}$. Untuk nilai CAPE sebelum kejadian hujan lebat dan angin kencang pada jam 06.00 UTC hingga $09.50 \mathrm{UTC}$ sebesar $705 \mathrm{~J} / \mathrm{kg}$ sampai dengan $822 \mathrm{~J} / \mathrm{kg}$. Hal ini menunjukkan bahwa adanya ketidakstabilan atmosfer dalam fase lemah.

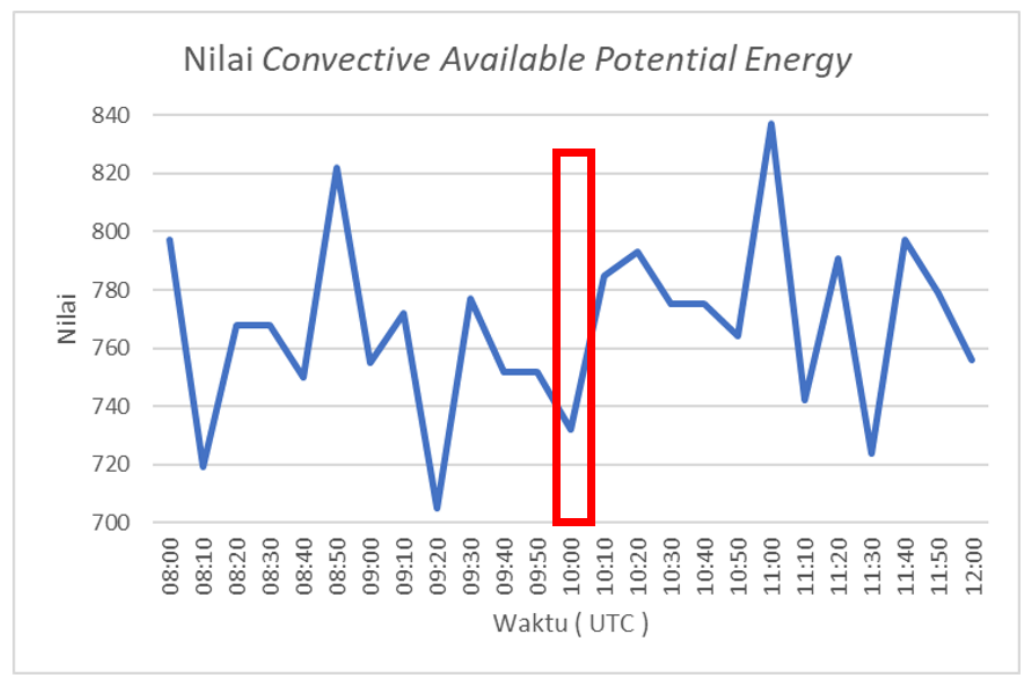

Gambar 14. Grafik nilai Convective Avaible Potential Energy (CAPE) 


\subsection{Analisis Citra Satelit}

\subsubsection{Analisis Suhu Puncak Awan}

Berdasarkan Gambar 15, suhu puncak awan pada 3 Januari 2020 pukul 17.00 WIB di wilayah Pajarakan ditunjukkan oleh lingkaran yang berwarna merah. Suhu puncak awan saat terjadi hujan lebat dan angin kencang sebesar $-70{ }^{\circ} \mathrm{C}$ hingga -80 ${ }^{\circ} \mathrm{C}$. Hal ini menunjukkan bahwa kemungkinan penyebab terjadinya hujan lebat dan angin kencang di wilayah Pajarakan awan cumulonimbus suhu puncak awan yang lebih dari $-70^{\circ} \mathrm{C}$.

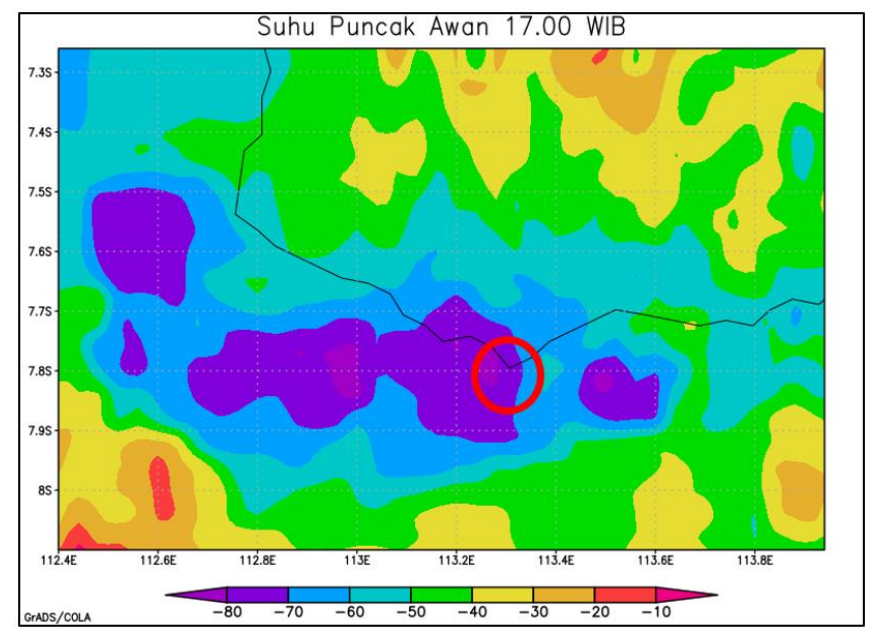

Gambar 15. Suhu puncak awan pukul 17.00 WIB

\subsubsection{Analisis Kontur Suhu Puncak Awan}

Berdasarkan Gambar 16, kontur suhu puncak awan di wilayah Pajarakan di tunjukkan pada lingkaran yang berwarna merah, terlihat bahwa awan dengan suhu puncak $-73.1^{\circ} \mathrm{C}$ yang luas menyelimuti wilayah Pajarakan. Sedangkan suhu puncak awan disekitarnya memiliki suh sebesar $-33.1^{\circ} \mathrm{C}$ hingga $63.1{ }^{\circ} \mathrm{C}$. Suhu puncak awan yang mencapai lebih dari $-70{ }^{\circ} \mathrm{C}$ ini mengindikasikan bahwa penyebab terjadinya hujan lebat dan angin kencang di wilayah Pajarakan adalah awan cumulonimbus.

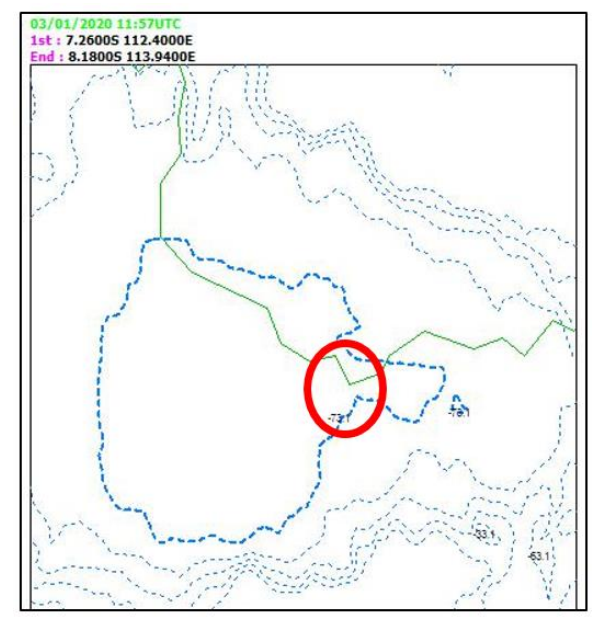

Gambar 16. Kontur suhu puncak awan pukul 17.00 WIB 


\subsubsection{Analisis Time Series}

Berdasarkan Gambar 17, kotak berwarna merah menunjukkan suhu puncak awan pada 3 Januari 2020 pukul 10.00 UTC. Terlihat bahwa suhu puncak awan saat terjadinya hujan lebat dan angin kencang sebesar $-73.1{ }^{\circ} \mathrm{C}$. Pada pukul 00.00 UTC hingga 09.50 UTC terlihat awan mengalami fase pertumbuhan dengan penurunan suhu dari $8{ }^{\circ} \mathrm{C}$ hingga $-73.1^{\circ} \mathrm{C}$. Pada pukul 08.00 UTC hingga 09.50 UTC terjadi penurunan suhu yang sangat signifikan dari $0{ }^{\circ} \mathrm{C}$ hingga mencapai $-70{ }^{\circ} \mathrm{C}$. Awan mengalami fase matang pada pukul 10.00 UTC hingga 14.00 UTC, kemudian awan mengalami fase pelurahan dengan adanya kenaikan suhu yang sangat signifikan pada pukul 14.10 UTC hingga 22.00 UTC.

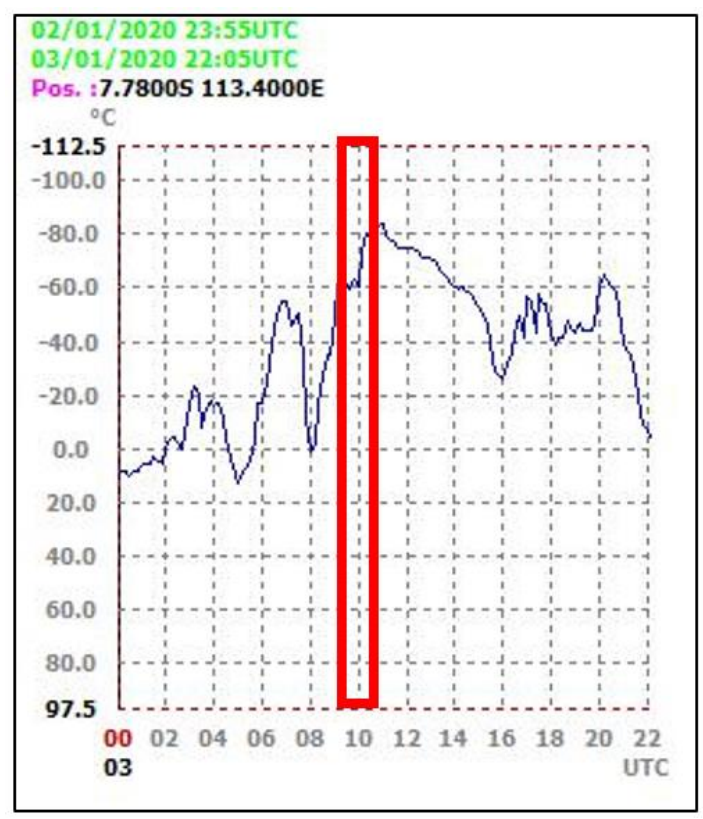

Gambar 17. Time Series suhu puncak awan

\subsection{Analisis Citra Radar}

\subsubsection{Analisis Produk Reflektivitas CMAX Overlay SWI}

Berdasarkan Gambar 18, wilayah Pajarakan pada 3 Januari 2020 pukul 10.00 UTC ditunjukkan dengan lingkaran berwarna merah yang memiliki nilai reflektivitas sebesar $43 \mathrm{dBz}$ menunjukan adanya cluster gugusan awan konvektif yaitu awan cumulonimbus yang cukup kuat. Dengan melakukan overlay CMAX dengan SWI terlihat bahwa adanya storm yang ditandai dengan warna merah serta adanya konvergensi di wilayah Pajarakan. 


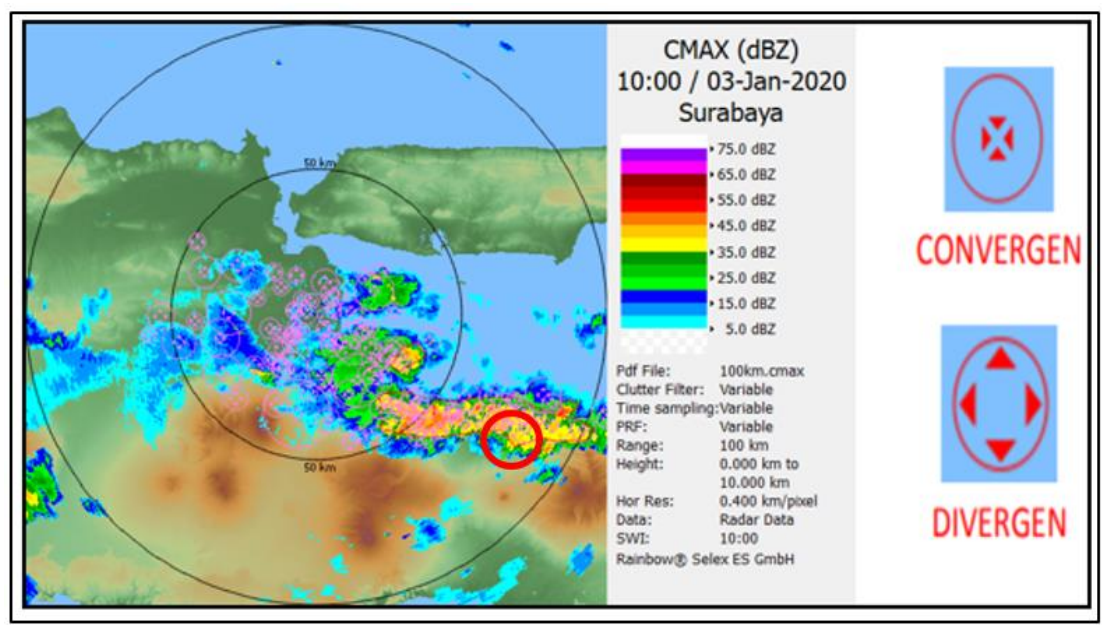

Gambar 18. Produk Reflektivitas CMAX Overlay SWI

\subsubsection{Analisis Produk CAPPI Velocity}

Berdasrkan Gambar 19, wilayah Pajarakan pada 3 Januari 2020 pukul 10.00 UTC ditunjukkan dengan lingkaran berwarna merah. Hasil Produk CAPPI velocity memberikan nilai velocity sebesar $-13.57 \mathrm{~m} / \mathrm{s}$ yang berarti mendekati radar dan termasuk dalam kategori angin kencang.

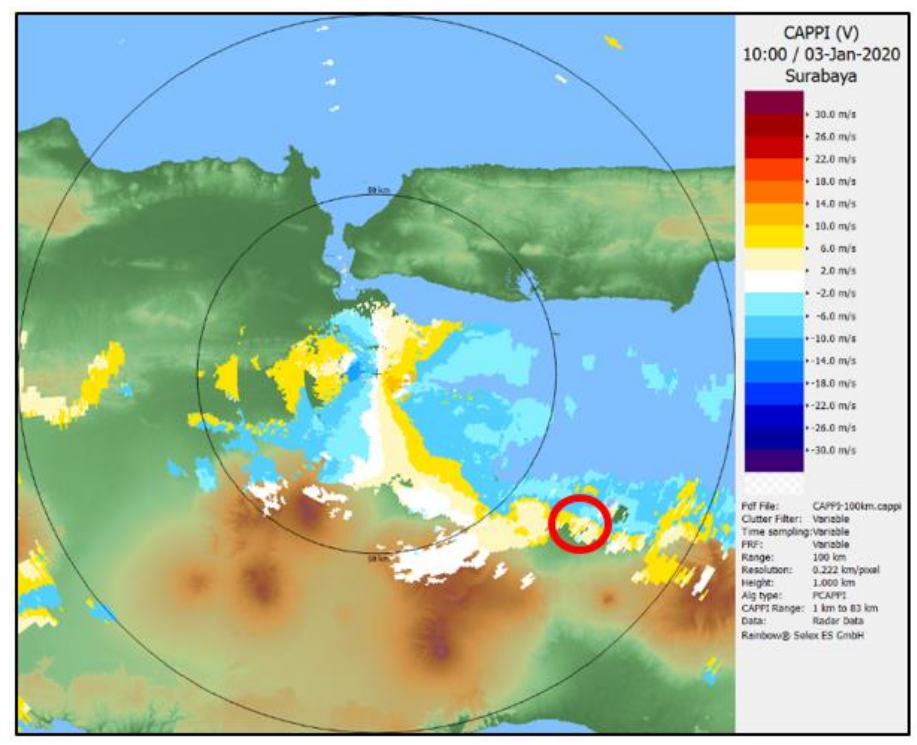

Gambar 19. Produk CAPPI Velocity

\subsubsection{Analisis Produk CAPPI Velocity}

Berdasrkan Gambar 20, wilayah Pajarakan pada 3 Januari 2020 pukul 10.00 UTC ditunjukkan dengan lingkaran berwarna merah. Hasil produk SRI memberikan jumlah intensitas curah hujan di permukaan. Terlihat bahwa wilayah Pajarakan memiliki curah hujan sebesar 15,83 mm/jam yang termasuk kategori hujan lebat. 


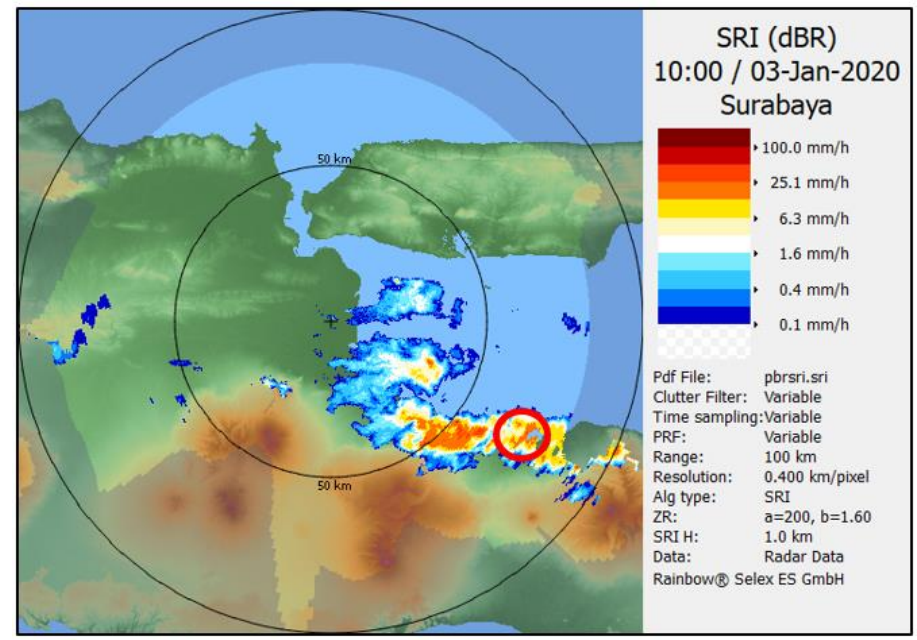

Gambar 20. Produk SRI

\section{Kesimpulan}

Berdasarkan hasil analisis kondisi atmosfer pada Desa Pajarakan, Probolinggo, Jawa Timur terkait dengan kejadian hujan lebat dan angin kencang pada tanggal 3 Januari 2020 pukul 17.00 WIB, maka dapat disimpulkan bahwa:

1. Berdasarkan analisis cuaca dalam skala global anomali SST memiliki nilai yang diatas normal yaitu sebesar $1.6^{\circ} \mathrm{C}$ hingga $1.8{ }^{\circ} \mathrm{C}$ yang menjadi faktor yang pendukung pertumbuhan awan-awan konvektif di wilayah Probolinggo

2. Berdasarkan analisis cuaca dalam skala regional dapat dilihat adanya shearline dan pertemuan dua massa udara di wilayah Probolinggo sehingga menyebabkan adanya konvergensi yang memicu pertumbuhan awan-awan konvektif di wilayah Probolinggo

3. Berdasarkan analisis secara lokal, nilai $\mathrm{RH}$ yang tinggi sebesar $85 \%$ hingga 90\% menunjukan banyaknya kandungan uap air di atmosfer. Nilai vortisitas yang negatif dari lapisan $1000 \mathrm{mb}$ hingga $500 \mathrm{mb}$ menunjukkan bahwa adanya gerakan siklonik di Desa Pajarakan, Probolinggo yang memicu pertumbuhan awan-awan konvektif. Labilitas atmosfer yang labil, sebelum dan saat terjadinya hujan lebat dan angin kencang mengindikasikan bahwa adanya potensi hujan lebat dan angin kencang di Desa Pajarakan. Dari hasil analisis citra satelit suhu puncak awan pada pukul 10.00 UTC sebesar $-71.3{ }^{\circ} \mathrm{C}$ yang mengindikasikan bahwa penyebab hujan lebat dan angin kencang adalah awan cumulonimbus. Dari hasil analisis citra radar, nilai reflektivitas sebesar $43 \mathrm{dBz}$ dengan adanya storm dan pola konvergensi serta kecepatan angin yang mencapai $13.57 \mathrm{~m} / \mathrm{s}$ dan intensitas curah hujan sebesar $15,83 \mathrm{~mm} / \mathrm{jam}$ menunjukkan bahwa benar adanaya kejadian hujan lebat dan angin kencang di Desa Pajarakan, Probolinggo, Jawa Timur

\section{Ucapan Terima Kasih}

Penulis mengucapkan terima kasih kepada Badan Meteorologi Klimatologi dan Geofisika (BMKG) dan National Oceanic and Atmospheic Administration (NOAA) yang telah memberikan akses penyediaan sumber data. Terima kasih juga untuk Sekolah Tinggi Meteorologi Klimatologi dan Geofisika (STMKG) yang telah 
membantu dalam memeberikan sistem aplikasi pengelohan data. Serta ucapan terimakasih kepada Bapak Aditya Mulya, SST, M.Si selaku dosen mata kuliah praktek mata kuliah satelit cuaca yang telah memberikan arahan dan bimbingan sehingga jurnal ini dapat terselesaikan.

\section{Daftar Pustaka}

1. Endarwin. Analisa Objektif Terhadap Kejadian Cuaca Ekstrim di Indonesia Memanfaatkan Data Satelit Cuaca, Prosiding Workshop Cuaca Ekstrim, 2012, Vol. I No. 19. Hal. 1-3.

2. Tjasyono, B. H. K., Meteorologi Terapan, Penertbit ITB, Bandung, 2008.

3. A. Zakir, W. Sulistya, dan M. Khotimah, Perspektif Operasional Cuaca Tropis. Badan Klimatologi dan Geofisika, Jakarta, 2010.

4. Sampe, Eusebio Andronikos. "Analisis Cuaca Terkait Kejadian Angin Kencang Di Kendari Tanggal 1 Maret 2017.” BMKG, 2017.

5. Fadholi, Akhmad. Kajian Metorologi Terkait Hujan Lebat Di Pulau Bangka Tangggal 28-29 Desember 2013. Buletin Megasains GAW Bukit Kototabang, vol. 6, 2015, pp. 129-40. 